\title{
AUSONIUS COMES SACRII CONSISTORII, VIR SPECTABILIS
}

U Podstrani kod Splita otkriven je fragment veoma važnog natpisa u kojem se utvrđuju neke zemljišne odredbe, što je očito predmet spora između nepoznatih sporitelja. Natpis je objavio M. Zaninović u dva istovjetna rada. Zaninovićevu čitanju i tumačenju autor donosi nekoliko dodataka i poboljšica. Novost je što se donošenje odluke pripisuje Juliju Auzoniju, prefektu pretorija čitavog Ilirika i članu carskog vijeća te savjetniku za Dalmacije (dvije). Riječ je o ocu velikog rimskog pjesnika Decima Maksima Ausonija, čijim je zalaganjem i otac, po profesiji liječnik, dobio važnu političku funkciju. Predmet spora po svoj je prilici nekadašnje imanje Lucija Artorija Kasta, znamenite vojne i civilne ličnosti, jer je velik i važan natpis potonjega nađen u neposrednoj blizini. Tako je Artorijev natpis logično povezati uz ovaj koji spominje Julija Ausonija. Po svoj prilici Artorijevo imanje predmet je spora nakon što su izumrli njegovi potomci. Auzonijev natpis pouzdano se datira u razdoblje 375. - 378., kad je obnašao funkciju prefekta iliričkog pretorija u Sirmiju.

Ključne riječi: Podstrana; decim Maksim Auzonije; Julije Auzonije; Lucije Artorije Kast i zemljišni spor.

U Podstrani, stotinjak metara sjevernije od crkvice sv. Martina, godine 1976. otkriven je povijesno i kulturološki iznimno važan natpis, nažalost, fragmentiran sa svih strana osim na lijevoj, gdje je sačuvana prazna traka i plitka okomito položena ordinacijska crta (sl. 1). Od vanjskog ruba spomenika do pravilno uklesanih slova po okomici razmak je 0,09. m. ${ }^{1}$ Počeci redaka nisu jednako udaljeni od spomenutog ruba. Visina spomenika iznosi $0,35 \mathrm{~m}$, a širina $0,54 \mathrm{~m}$. Na temelju toga moglo bi se pretpostaviti da je na desnoj strani bilo mjesta za još najviše tri slova i prazni natpisni obrub od 0,09 m kao na lijevoj strani, što daje ukupnu širinu spomenika od oko 0,75 m. Visinu je, naravno, nemoguće odrediti, ali pod pretpostavkom da je natpis bio pravokutan i da je stajao uspravno te da je

$1 \quad$ Tadašnja djelatnica Regionalnog zavoda za zaštitu spomenika kulture u Splitu J. Jeličić o nalazu je obavijestila profesora M. Zaninovića i prepustila mu objavu. Objava je uslijedila godine 1987. M. Zaninović 1986. - 1987., 11-22. Članak je pretiskan u M. Zaninović 1996. 375-384. Koliko mi je poznato, o tom natpisu poslije više nitko nije pisao, a rijetko se spominje u literaturi. 
na toj površini bilo oko 12 - 14 redaka - mogla je iznositi oko 1,20 m. U recima je bilo 19 - 21 slovo uključujući razdjeljke među retcima.

U izvrsnoj obradi M. Zaninović natpis otčitava: SVIS I

IVS NEGABATVR VE...

NVNC TEMPORIBVS PE.

SIMIS VIR SPECTABILI.

AVSONIVS COMIS SACR..

CONSISTORII ET DALMAT.

RVM CONSVLENS PE...

...M HON..
Zaninović razrješava:

suis (?) i[tem ?]

ius negabatur ve[nandi vel veniendi?]

nunc temoribus pe[s]

simis vir spectabili[s]..

Ausonius comis sac[ri]

consistorii et Dalmat[ia]

rum consulens pe[rfe

ctissimus que]m hon[o

rem] ...]

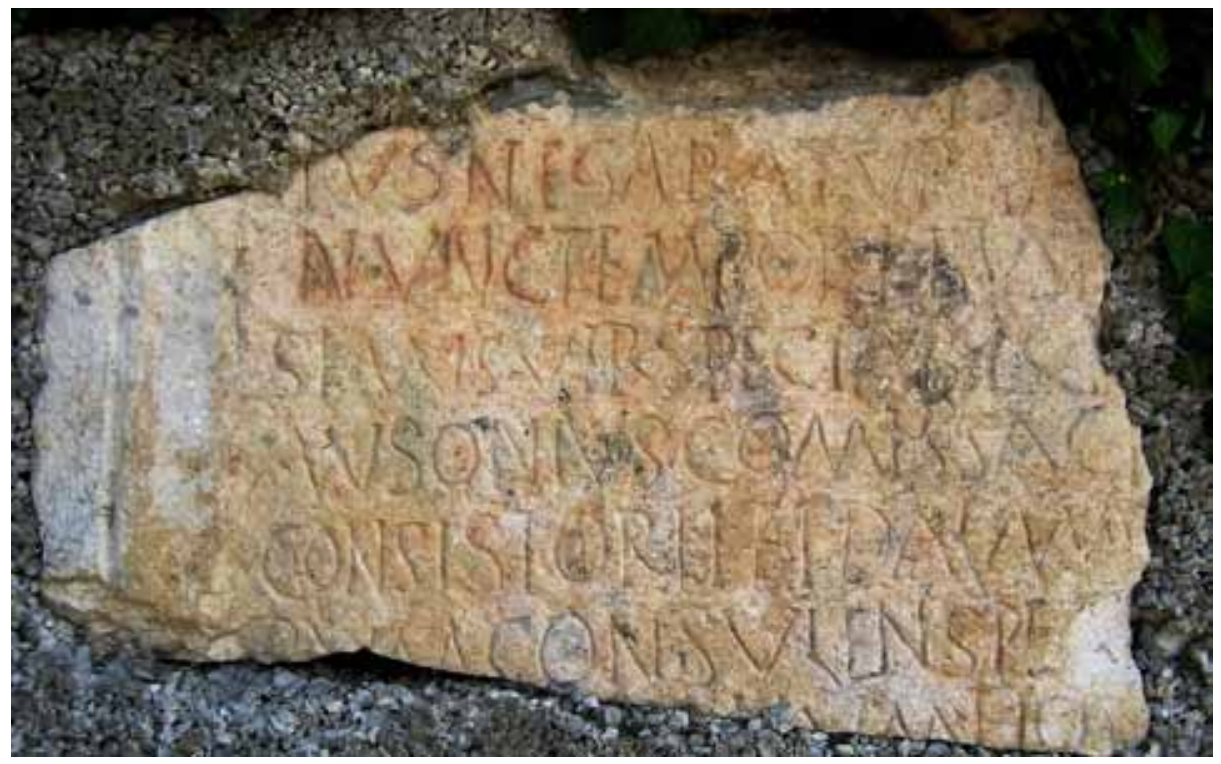

SI. 1. Ausonijev natpis iz Podstrane kod Splita

Fig. 1. The Ausonius Inscription from Podstrana near Split 
Natpis ne pruža veće teškoće $u$ čitanju osim, naravno, u dva fragmentarno očuvana retka (prvom i posljednjem). Nažalost, ne može se ni približno pretpostaviti koliko je ukupno bilo redaka. To je velika šteta jer su se na početku i na kraju nalazile najvažnije sadržajne stavke (svrha postavljanja natpisa, odluka i sankcija), a povod je, prema očuvanom dijelu teksta, nedvojbeno bio veoma važan. Zaninović se potrudio i korektno pročitao natpis. Međutim, promatrajući pozorno ostatke prvog sačuvanog retka, prvo slovo nije $S$ nego $Q$, na što upućuje oblik zakrivljenja donjeg dijela koji je različit od onoga na u natpisu višekratno očuvanom slovu S. Ako je doista riječ o slovu Q, onda se doista otvaraju neke nove mogućnosti utvrđivanja karaktera natpisa. Osim toga, riječ suis ne upućuje ni na što, dok quis omogućuje da se taj redak može još popuniti sa si ]quis, te se sadržaj smisaono bolje povezuje s onim što slijedi, a to je upozorenje da, ako bi tko u tadašnjim teškim vremenima negirao nečije pravo, slijedi da je Auzonije comes sacri constistorii i consulens Dalmatiarum u tom slučaju nešto odlučio. Po svoj prilici radilo se o pravu prodaje ili pak o pravu prolaza. ${ }^{2}$ Prvo bi bilo logičnije ako se radilo o smetnji posjeda, a drugo je osobito dobro poznato $u$ sepulkralnoj sferi, kad raspored nadgrobnih spomenika mora biti takav da omogućuje slobodan prolaz do pojedinog groba (locus sepulturae). ${ }^{3}$ Ovdje međutim nije riječ o nadgrobnom natpisu, pa bih bio skloniji pretpostavci da su u pitanju zemljišni imovinski odnosi koji su često bili takvi da je u teškim vremenima dolazilo do uzurpacija i zabrane prolaza. Čak i danas česte su parnice u svezi s ometanjem posjeda, a tiskovine su prepune takvih vijesti. Stoga je vjerojatnije da je netko vlasniku osporavao pravo posjedovanja. Ako tko osporava pravo vlasnosti, tada ni prodaja nije moguća, jer, kako bi se to danas reklo, prodavatelj nema „,̌iste“ papire. Problem je morao biti golem kad u rješavanju spora sudjeluje Auzonije (Ausonius) comes sacri consistori sa staleškim naslovom vir spectabilis. M. Zaninović već je u naslovu nagovijestio da se radi o novom i dotada nepoznatom namjesniku rimske provincije Dalmacije. ${ }^{4}$ Po Zaninovićevu razmišljanju, Auzonije je namjesnik rimske provincije Dalmacije i član spomenutog carskog vijeća koji je još bio i consulens Dalmatiarum. Naziv sacrum consistorium po prerogativima i dužnostima zamijenio je consilium principis (carsko vijeće) iz doba principata, što je zapravo savjetodavno tijelo koje pomaže caru u donošenju odluka, a javlja se od Konstantina I. ${ }^{5}$ Taj naziv poznat je, doduše, još od Dioklecijana i nastao je prema terminu koji je izvorno označavao svečanu carsku dvoranu (consistorium, aula re-

\footnotetext{
M. Zaninović se ne odlučuje za jednu od te dvije mogućnosti.

3 N. Cambi 2010., 72-80.

4 M. Zaninović 1996., 376.

5 Th. Mommsen 1874/87., 989; O. Seeck 1900, 926-932; A. Demandt 2007. 276-277.
} 
gia) u kojoj se tijekom IV. st. sastajao carski savjet. ${ }^{6}$ Članovi toga savjeta nazivaju se comites intra consistorium, comites consistoriani ili comites primi ordinis i nosili su naziv viri illustres. ${ }^{7}$ Comites nižeg ranga nose naslov viri spectabiles. Zadaća savjetnika bila je savjetovati caru kad je primao poslanike te pismene ili usmene zamolbe. Vijećanje se rijetko održavalo u velikom krugu nego su se rasprave vodile u užem krugu povjerljivih ljudi, tzv. proximi. Odluke su se protokolirale, a pisma su se pečatirala i odašiljala. ${ }^{8}$

U skladu s gornjim, Auzonije na spomenutom natpisu iz Podstrane bio je član carskog vijeća drugog ranga (viri spectabiles). Tko je taj Auzonije? Vidjeli smo već da je Zaninović pretpostavljao da je riječ o dosad nepoznatom namjesniku rimske provincije Dalmacije. Valja naglasiti da je kognomen Ausonius rijedak, da se $\mathrm{u}$ Dalmaciji spominje samo u jednom slučaju, ${ }^{9}$ a ni u Rimu nije poznat. ${ }^{10}$ Taj je cognomen grčkog podrijetla. ${ }^{11}$ Auzon je naime sin Odiseja i Kirke. ${ }^{12}$

U slučaju natpisa iz Podstrane ipak s dobrim razlozima valja pomišljati na nekog od dva poznata Auzonija. Prvi je Julius Ausonius (oko 290. - 378.), liječnik grčkog podrijetla iz Bordeauxa, a drugi je njegov sin, veliki latinski pjesnik IV. st. Decimius Magnus Ausonius, rođen 310. u Burdigali u jugozapadnoj Galiji, koji je umro oko 395. u rodnom gradu. ${ }^{13}$ I otac i sin obnašali su važne političke dužnosti. Unatoč političkim karijerama, ni jedan ni drugi nisu napustili svoja prava zvanja: prvi liječništvo, drugi poeziju, odvjetništvo i govorništvo. Mlađi Auzonije stekao je sjajno obrazovanje u Bordeauxu i Toulouseu, gdje mu je majčin ujak Aemilius Magnus Arborius bio profesor. Kad mu je ujak pozvan u Konstantinopol kao tutor jednog od sinova cara Konstantina, Auzonije odlazi s ujakom, gdje se još potpunije usavršava. ${ }^{14}$ Poslije povratka u Galiju car Valentinijan I. poziva mlađeg Auzonija da bude odgojitelj sinu mu Gracijanu. K tomu odmah dobiva i službu kvestora. Kad je pak Gracijan postao carem godine 375., on

A. Demandt 2007., 277.

A. Demandt 2007., 277.

A. Demandt 2007., 277.

9 G. Alföldi 1969., 160. Naime u južnoj Dalmaciji (Doclea) spominje se jedna žena s tim nadimkom (CIL III 13845).

10 G. Alföldi 1969., 160. Toga kognomena nema u repertoaru koji donosi I. Kajanto 1965.

11 Usp. W. Pape 1884.,179.

Der Kleine Pauly I, 774.

13 Obitelj Ausonia iz Burdigale imala je izuzetan osjećaj obiteljskog zajedništva. Pjesnik Auzonije često spominje svoje obiteljske prilike, zgode i velik broj raznih osoba, osobito u spjevu Parentalia. Međutim, i u drugim pjesmama on veliča bilo mrtve bilo žive članove obitelji s očeve i majčine strane. Usp. J. Evans Grubbs 2012., 201-206. 
i njegova obitelj dobivaju mnoge važne službe i počasti. Mlađi Ausonije postaje pretorijanski prefekt Galije, dok njegov otac s gotovo devedeset godina, kako mu sin kaže u jednom stihu, postaje prefekt čitavog Ilirika. Godine 376. Auzonijev posinak, Hesperije, imenovan je prokonzulom Afrike. Godine 379. Ausonije je dobio konzulat, što je njegov najveći domet u karijeri. Kad se godine 383. vojska u Britaniji pobunila i u Lyonu ubila Gracijana te kad je Valentinijan II. otjeran iz Italije, mlađi se Auzonije vraća u rodni grad, kako kaže - gnijezdo svoje starosti (nidus senectutis), gdje živi do smrti. Otac mu je umro 378., dakle još prije promjene političke situacije. Stariji Auzonije bio je poganin i pod utjecajm filozofije kasnoantičkog poganstva. Naprotiv, sin mu pjesnik, čini se, oduševljeno je prihvatio kršćanstvo, ali tek u kasnijem razdoblju svoga života. Kako mu je i unuk bio pjesnik (Paulin iz Pelle), očito je da je obitelj bila nadarena i da je posjedovala velike intelektualne mogućnosti s kojima se združila i znatna politička moć na lokalnoj i općoj rimskoj razini. ${ }^{15}$

Koji bi od navedena dva Auzonija mogao biti osoba iz podstranskog natpisa? Iako se rješenje lako nazire, ono ipak nije posve jednostavno. Problem je naime je li otac Auzonije mogao biti comes sarcri consistorii ili ne. Za mlađeg bi se sa sigurnošću smjelo kazati da je u doba Gracijana, za kojega je obnašao čak i dužnost konzula, mogao biti jedan od bliskih savjetnika (proximus). S konzulskom čašću po svoj prilici išlo je i imenovanje carskim savjetnikom (comes sarci consistorii). S druge strane, to nije sigurno za oca. Međutim, vrhunac karijere sina bio je kad je, također u visokim godinama, 375. došao do najviših časti. S obzirom na to da je otac samo 20 godina stariji od sina, sinov utjecaj na Gracijana omogućio je da otac dobije funkciju prefekta čitavog Ilirika, što je u našem slučaju ključno. Ako se podstranski natpis doista odnosi na oca, tj. Julija Ausonija, tada dobivamo i pouzdanu dataciju natpisa u vrijeme između 375. i 378. Kako je potonji umro 378., gotovo je pouzdano da je na funkciji ostao do kraja života. ${ }^{16} \mathrm{Kad}$ bi se radilo o samom pjesniku, tada bi se mogućnost datacije natpisa protegnula sve do 383., ali to je znatno manje vjerojatno, jer potonji nije imao nikakve administrativne ingerencije na području Dalmacije.

Zašto je vjerojatnije da je u pitanju stariji Auzonije? Prije svega riječ je o rješavanju nekog problema u vezi s mogućim osporavanjem nekog zemljišnog posjeda u Podstrani (Pituntium). Logičnije je da to rješava prefekt Ilirika u čiju

$\overline{15}$ O Auzoniju pjesniku usp. F. Marx 1902., 2562-2580 s.v. Ausonius Decimus Magnus; H. Sivain 1993; Enzyklopädie der Antike II 1997., 333-335; A. Coskun 2002; Cambridge Ancient History XIII, 2008., 673-674, 691-692; Ausonius, Opuscula Omnia 2010. Literatura je opsežna.

O starijem Ausoniju usp. O. Seeck 1902., 252, te mnoge naslove spomenute u bilj. 10. u vezi sa sinom mu Decimom Maksimom Auzonijem. Zanimljivo je da oca ne spominje Der Neue Pauly. Enzyklopädie der Antike II, Stuttgart-Weimar 1997, ali je kratko ipak spomenut u Kleine Pauly I, 774 
nadležnost ulaze i obje Dalmacije, o čemu bi govorio i naslov consulens Delmatiarum (skrbnik obiju Dalmacija). To je, kako Zaninović pretpostavlja, varijanta naslova consularis, o čemu ima svjedočanstava u izvorima i u natpisima.17 U Gracijanovo doba mlađi Auzonije bio je opterećen drugim važnijim pitanjima. Nakon Gracijanove smrti mlađi se Auzonije povlači u Galiju i ne obnaša više nikakve dužnosti. Stoga nam se prikloniti zaključku da je riječ o starijem Auzoniju i nadopuniti sljedeći (nedostajući) redak per[fectissimus praefectus Illyrici um ho/... Puni izraz za službu bio bi praefectus praetorio, ali obje riječi teško da bi stale $\mathrm{u}$ dosta uzak natpis u prostoru retka bez mogućnosti kraćenja, jer bi to iznosilo znatno više od 21 slova. Zaista je velika šteta što natpis nije cjelovito očuvan, jer bismo tako imali zabilježen zemljišni spor koji pravno rješava ured prefekta Ilirika. Natpis je vjerojatno navodio o kojem se prediju radilo i druge podatke relevantne za spor. No, iako su lomovi natpisa stari, otkriće tog središnjeg dijela natpisa daje nadu da bi se mogli pronaći i ostali dijelovi na parceli danas u vlasništvu obitelji Banić.

Prema iznesenom, natpis bi glasio:

si quis i[tem]/ivs negabator ve[nandi/nunc temporibus $p$ [es]/simis vir spectabilis]/Ausonius comis sacr[i] consistorii et Dalmatia/rum consulens per[/fectissimus praefectus (praetorio) Illyrici ... um ho

Dakle novi namjesnik bio bi otac pjesnika Auzonija, na čiji ga je poticaj Gracijan imenovao na funkciju prefekta koja je obuhvaćala čitav Ilirik (osim Trakije) prema reformi iz doba Konstancija II. ${ }^{18}$ Sjedište mu je bilo u Sirmiju, poslije Gracijanove smrti seli ga u Solun. Tada je već stariji Auzonije mrtav. Dužnost praefectus praetorio bila je prvotno vojna funkcija koja se $u$ kasnoj antici pretvorila u civilno-administrativnu. Koja su to teška vremena u natpisu i na što se tim izrazom misli, nije jasno. Nevolje su se u Rimskom Carstvu množile i perpetuirale od Valentinijanove smrti 375. pa nadalje: kao što je imenovanje mlađeg mu brata Valentinijana II. za cara, smrt brata mu Valensa u bitci kod Hadrijanopola godine 378. i konačno Gracijanova ubojstva 383. S Gracijanom je završila politička karijera dvaju Auzonija. ${ }^{19}$ Aludira li natpis na te ili pak na neke druge događaje, teško je reći, ali neki posebni događaji u Dalmaciji, barem koliko je do sada poznato, nisu se događali u razdoblju 375. - 383. Tek krajem stoljeća,

\footnotetext{
17 A. Demandt 2007., 334-335.

18 J. Matthews 1975., 69-71.

19 O tome razdoblju usp. A. Cameron 1995., 125-141. Dostupan mi je bio samo talijanski prijevod autoričine knjige Later Roman Empire, London 1993.; A. Demandt 2007., 136-154.
} 
godine 395., Goti su došli do Salone. ${ }^{20}$ Izvješća o paležu i pljački Dalmacije u vezi sa stradavanjem rodnog mu Stridona podnosi sv. Jeronim na više mjesta. Te se vijesti također odnose na posljednje desetljeće IV. st. ${ }^{21}$ Stoga izraz temporibus pessimis možda podrazumijeva opću situaciju u carstvu prije Gracijanova ubojstva. Međutim možda je vjerojatnije da natpis aludira na loše odnose u svezi sa zemljišnom situacijom u samoj Podstrani (Pituntium).

Ovaj natpis odbacuje i jednu pretpostavku koja se činila veoma vjerojatnom i logičnom. Naime, A. Demandt pretpostavio je, doduše s upitnikom, da Julije Auzonije nije uopće stupio u službu iliričkog prefekta pretorija, naravno zbog starosti, i da je to bilo samo počasno imenovanje. ${ }^{22}$ Međutim, taj dalmatinski spor rješava Auzonije stariji kao consulens Dalmatiarum u carskom vijeću, što pobija spomenuto mišljenje, jer teško da bi počasna funkcija uključivala rješavanje sporova. Za to je nužno posjedovanje izvršne vlasti, što bi značilo da je Julius Ausonius, doduše kratko, ali ipak, obavljao dodijeljenu mu funkciju. Provincija u pitanju navodi se u množini - vjerojatno je to druga Dalmacija, odnosno njezin nekadašnji južni dio (Prevalis) koji je Dioklecijan odvojio kao samostalnu provinciju dijeceze Ilirika.

U natpisu je zabilježen zemljišni spor, ali koji i kakav nije jasno jer je natpis nepotpun. Fragment o kojem je riječ nađen je stotinjak metara sjevernije od rimske ceste (od Epetija do Oneja), očito na nekadašnjem posjedu Lucija Artorija Kasta, znamenite ličnosti bogate karijere, koji je nakon aktivne vojne i civilne službe umro u Podstrani te je pokopan početkom III. st. (sl. 2). ${ }^{23}$ Prema mjestu otkrića, logično bi bilo da se tekst natpisa odnosio upravo na probleme vezane s tim posjedom. S južne strane te ceste, koja se približno podudara sa suvremenom, bio je grobni areal i sarkofag Lucija Artorija Kasta. U većem Artorijevu natpisu stoji da je imenovani još za života izradio grobni areal sebi i svojima prema vlastitoj oporuci (vivus ipse sibi et suis ex testamento posuit), što znači da još ima izravnih ili neizravnih potomaka. Ipak, lako je moguće da je obitelj izumrla tijekom III. ili IV. st. pa da je taj golemi posjed koji se prostirao od mora pa do pod obronak Mosora postao državno vlasništvo i da je oko njega došlo do sporova (države i privatnika ili dvaju ili više privatnika). Imanje se nalazilo tek koji kilometar zapadnije od ilirske gradine Mutogras (Mons Crassus), koja stoji tik do mora u neposrednoj blizini ceste (sl. 3). Riječ je o iznimno plodnom zemlji-

\footnotetext{
20 Usp. J. J. Wilkes 1969., 416-420.

21 Jeronim, De viris illustris, CXXXV, Comm. In Sophon. Proph., 1, 2; Epistola Pamahiju IXVIB 14. Riječ je o izdanjima Migne Patrologia Latina.

22

A. Demandt, o.c. 144-145. bilj. 80.

23

N. Cambi 2014. 29-40.
} 
štu osobito pogodnom za uzgoj mediteranskih kultura. Imanje je bilo cestovno, a i morskim putem dobro povezano s obalnim i unutrašnjim područjima Dalmacije. Veliki mlin za masline (u Dalmaciji do sada nije pronađen veći) stoji i danas na groblju uz crkvicu sv. Martina i svjedoči o bogatom urodu te uljarice (sl. 4). ${ }^{24}$ $\mathrm{S}$ obzirom na nalaze arhitekture, stupova i građevinskih elemenata, sjevernije od ceste bila je i Artorijeva villa u kojoj je vlasnik nakon službe starost proveo sa svojim ukućanima (bliža i dalja obitelj). Ta dva iznimna natpisa po svoj su prilici u međusobnoj vezi i govore i o sporu u kasnije doba te o načinu rješavanja sporova na razini provincijalne uprave kojoj je na čelu prefekt zadužen za probleme Dalmacije. Spor se po svoj prilici rješavao u konzistoriju, a izvješće je podnio Auzonije stariji u funkciji koju je obnašao. Prefekt Julije Auzonije važna je ličnost kasne antike koja je aktivno sudjelovala u rješavanju gorućih problema među kojima je ovaj natpis samo pokazatelj teškog stanja u dalmatinskom katastru. $^{25}$

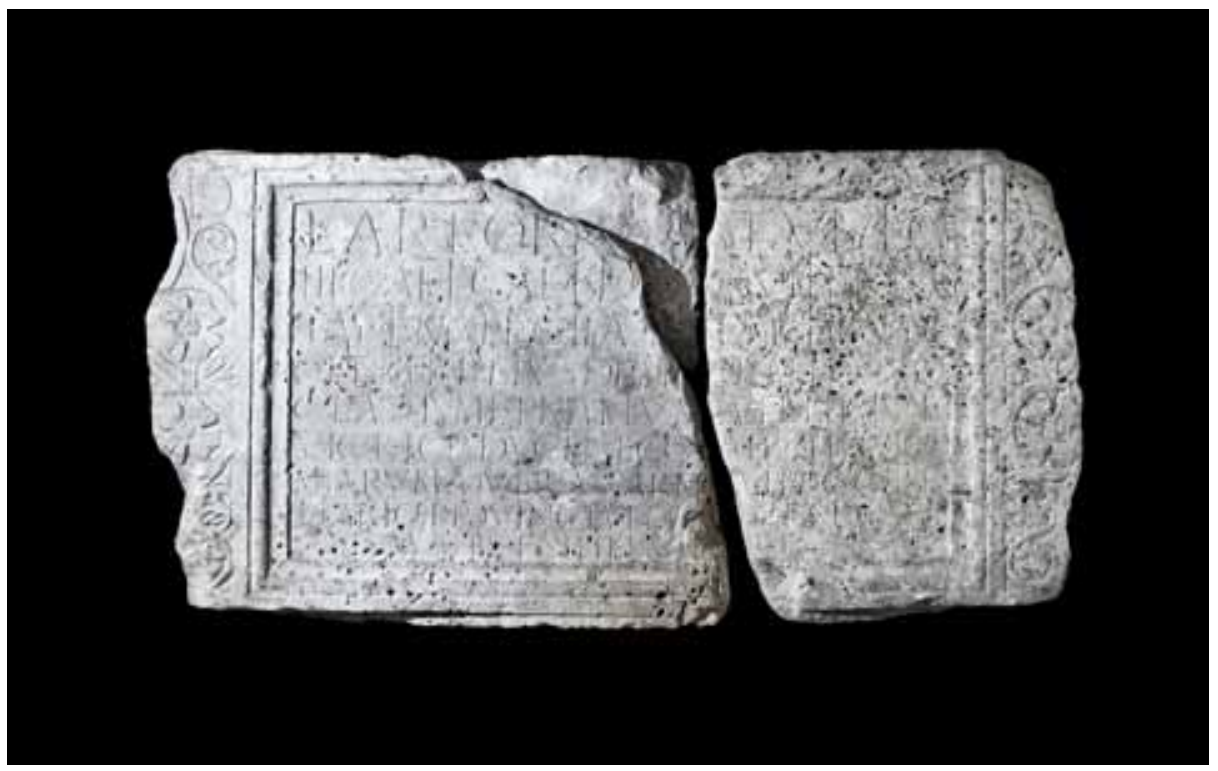

SI. 2. Natpis Lucija Artorija Kasta iz Podstrane

Fig. 2. The Lusius Artorius Castus inscription from Podstrana

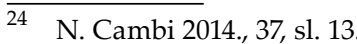

25 Moguće je da je Auzonije stariji u svojstvu consulesa Dalmatiarum morao preuzeti Kastovo imanje za državni patrimonij kao što je Epiphanius vir spectabilis u svojstvu consularis Dalmatiae morao preuzeti imovinu Ivane, žene Andrijine, koja je umrla bez nasljednika u VI. stoljeću, dakle u znatno kasnije doba, za državni patrimonij. Usp. R. Matijašić Zagreb 2012., 173. 


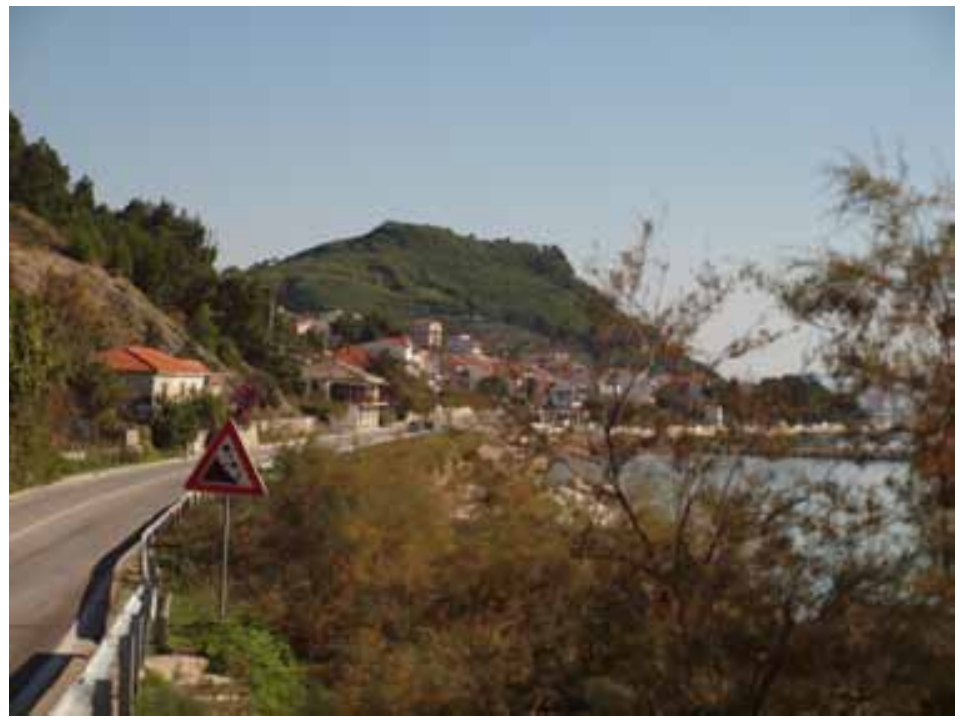

SI. 3. Pogled na gradinu Mutogras istočno od Podstrane s grobišnog areala Lucija Artorija Kasta Fig. 3. View on the hill-fort Mutogras eastern of Podstrana (from the funerary areal of Lucius Artorius Castus

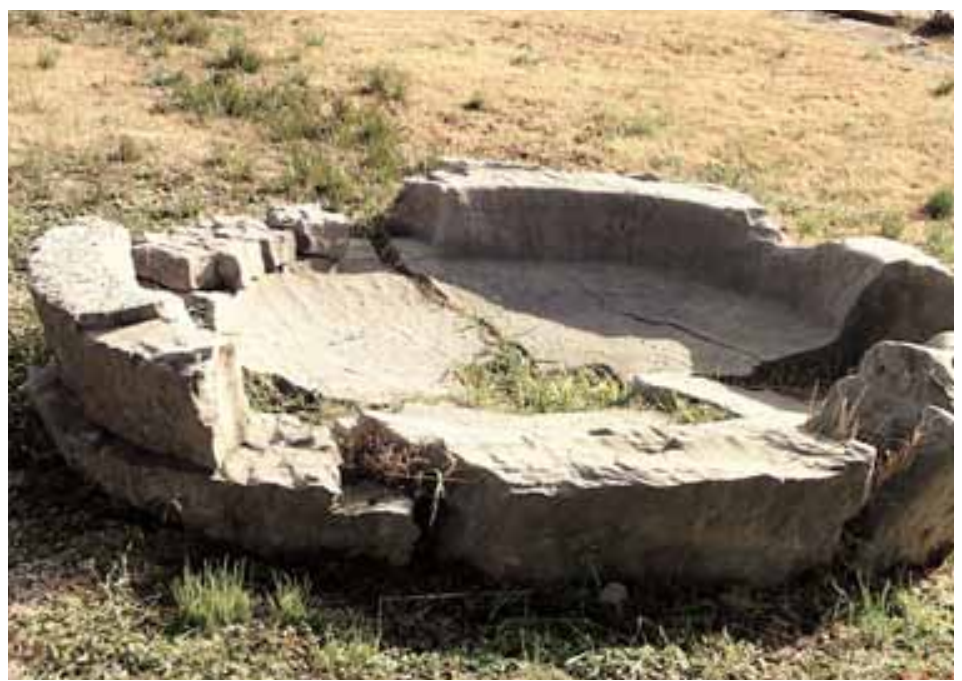

SI. 4. Veliki mlin za preradu ulja na grobnom arealu Lucija Artorija Kasta u Podstrani Fig. 4. The big mill for olives. Lucius Artorius Castus funerary areal al Podstrana 


\section{Literatura}

ALFÖLDI G., Die Personnenamen in der römischen Provinz Dalmatia, Heidelberg 1969. AUSONIUS, Opuscula Omnia, Oevres complètes, ed. B. Combeaud, 2010 Mollat. Book. CAMBI N., Sarkofazi lokalne produkcije u rimskoj Dalmaciji, Split 2010.

CAMBI N., Lucije Artorije Kast: njegovi grobišni areal i sarkofag u Podstrani (Sveti Martin) kod Splita, u Lucije Artorije Kast i legenda o kralju Arturu (Lucius Artorius Castus and the of King Arthur Legend), Zbornik radova s međunarodnog skupa održanog u Podstrani od 30. ožujka do 2. traonja 2012., Split 2014 (ur. N. Cambi i J. Matthews), 29-40.

Cambridge Ancient History XIII, Cambridge University Press 2008., 673-674, 691-692 (A. Cameron).

A., Il tardo Impero Romano, Bologna 1995. (talijanski prijevod knjige: Later Roman Empire, London 1993.).

A., Die gens Ausoniana an der Macht. Untersuchungen zu Decimius Magnus Ausonius und seiner Familie (Prosopographica et Genealogica 8.), Oxford 2002.

DEMANDT A., Die Spätantike. Römische Geschichte von Diocletian bis Justinian 284-565 n. Chr. München 2007. (sec. ed.).

Der Neue Pauly. Enzyklopädie der Antike II, Stuttgart-Weimar 1997., 333-335 s.v. Ausonius Decimus Maximus.

EVANS GRUBBS J., Marriage and Family Relationships in the Late Roman West, $\mathrm{u} A$ Companion to Late Antiquity, Wiley-Bleckwell Publishing Malden-Oxford 2012. 201-219 (ed. Ph. Rousseau).

MOMMSEN Th., Römisches Staatsrecht II, 1874/87., Leipzig 1877.

JONES A. H.M.- Martindale J. R. - Morris J., Decimius Magnus Ausonius, in The Prosopography of the Later Roman Empire. Vol. I (1971 Cambridge), s.v. Ausonius (J. Martindale).

MARX F., PW-RE II, 2, Stuttgart 1902., 2562-2580 s.v. Ausonius Decimus Magnus;

MATIJAŠIĆ R., Povijest hrvatskih zemalja u kasnoj antici od Dioklecijana do Justinijana, Zagreb 2012.

MATTHEWs J., Western Aristocracies and Imperial Court, AD 364-425, Oxford 1975.

SEECK O. Sacrum consistorium, PWRE IV, 1, 1900, 926-932.

PAPE W., Wörterbuch der griechischen Eigennamen, 3. Auflage bearbeitet von G. Benseler Braunschweig 1884.

SIVAN H., Ausonius of Bordeaux: Genesis of a Gallic Aristocracy, London 1993;

ZANINOVIĆ M., Ausonius vir spectabilis - Novi namjesnik kasnoantičke Dalmacije, Prilozi povijesti umjetnosti u Dalmaciji (posvećen Davoru Domančiću), 26, 1986. - 1987., 11-22.

ZANINOVIĆ M., Od Helena do Hrvata, Zagreb 1996. 375-384. 
SEECK O., Julius Ausonius PW-RE II, 2, 252.

WILKES J.J., Dalmatia, London 1969. 


\section{Nenad Cambi}

\section{Summary}

\section{Ausonius comes sacrii consistorii, vir spectabilis}

Some hundered meters northern of the church St. Martin a fragment of a very important inscription, was found at Podstrana in central Dalmatia in 1976. Now it is walled in the enclosure of thefence of Banić family house.The inscription has the smooth border and vertical deviding line of the margine. The letters of the text are rather regularly cut in the late antique style. The fragment is $0,35 \mathrm{~m} \mathrm{~h}$. and $0,54 \mathrm{~m} \mathrm{~b}$. The right side of the inscription is broken. Obviously only one to three letters are missing. The upper and lower part of the monument are also missing. M. Zaninović who published the inscription reads it as follows: suis (?) i[tem ?] / ius negabatur ve[nandi vel veniendi?] / nunc temoribus pe[s] / simis vir spectabili[s]../ Ausonius comis sac[ri]/ consistorii et/ Dalmat[ia]/ rum consulens pe[rfe] / ctissimus / que]m ho[norem ...].

The deciphering of the epigraph reveals not many difficulties. Unfortunately it is not known how many lines are missing. As it seems the first letter could not be $S$ but $Q$ according to the form of its lower part. This comes out from the comparison of theshape of the letter $S$ in other lines. If really it is so, the letter $\mathrm{Q}$ opens new possibilities of interpretation of the inscription character. Quis insead of suis suggests the following reading: si ]quis, which better suits to the inscription subject which is a kind of warning to the possible violator of the owner's low of possession. After that the name and the function of Ausonius, the comes sacri constistorii and consulens Dalmatiarum. Which kind of the juridical matter was the problem was in question, is not known, but very likely the exclusive right of proprietorship. Obviously, the conflict was very hard when Ausonius, comes sacri consistori bearing status title vir spectabilis took the part in the law-suit. M. Zaninović even in the title of his work mentioned that Ausonius is the new and until now not known governor of the Roman province of Dalmatia and the member of the emperor's council responsible fot both Dalmatiae (consulens Dalmatiarum).

Who was this Ausonius mentioned in Podstrana inscription? Zaninović assumed, as we have seen, that he was the unknown governor of Roman Dalmatia. However, he must be one of two very well known Ausonii. The first is Julius Ausonius (cca 290 to 378), the physician of Greek descent from Bordeaux while the second is his son the great Latin poet of $4^{\text {th }}$ century AD Decimius Magnus Ausonius born in 310. also in Burdigala who died cca 395 in his native town. The latter, when Gratian became the emperor in $375 \mathrm{AD}$ helped his family in obtaining many high honours and functions. Ausonius younger was appointed to the function of the pretorian prefect of Gaul. His father who was only about twenty years older than son and having almost ninety years was given the service of the pretorian parefect of the large region of Illyricum. 
The army in Britain during its apprisal in 383. killed Gratian in Lugudunum, Valentinian II was banished from Italy, while the younger Auspnius withdew to the native city where he lived until his death. His father died in 378. So it is very likely that the Ausonius father (Julius Ausonius) as the person in charge had to take the decision having also special responsability for Dalmatia. So, in the case that really the older Ausonius was in question. The inscription though must belong to the period between 375 and $378 \mathrm{AD}$. The see of the governor of Illyricum was Sirmium (Pannonia) which was transferred to Thessalonica in Greece after the death of Gratian.

The reading of Podstrana inscription is follwing: si] quis i[tem]/ivs negabator ve[nandi/nvnc temporibvs $p$ [es]/simis vir spectabilis]/Ausonius comis sacr[i] consistorii et Dalmatia/rom consvlens per[/fectissimvs praefectus (praetorio) Illyrici ...vm ho.... As it seems the last, fragmentarily preserved line should not be deciphered as: quem honorem since only the letters $v m$ and ho, which could not be read as quem honorem as was assemed by Zaninović.

The phrase temporibus pessimis is not quite clear since it could refer to the general bad situation in the empire. But, it should rather allud to the bad local relationships in the land registry at Podstrana (Pituntium).

The Podstrana epigraph is a clear evidence of the A. Demandt's conjecture was wrong that Julius Ausonius did not enter the service of praefectus praetorio because of his old age supposing. However, this Dalmatian agrarian conflict clearly required the full engagement of the consulens Dalmatiarum in person.

Since the fragment was discovered on the estate of Lucius Artorius Castus, an outstanding person who, after rich military and civil career, lived and died at Podstrana. His burial areal was partly found at Podstrana including two epitaphs from the early $3^{\text {rd }}$ century AD. The discovery site of Ausonius' inscription indicates that the cadastral problem was related to the ex Castus' possession. Big mill for making olive oil is now in the Castus burial areal near the church of St. Martin. As far as I know it is the bigest mill found in Dalmatia testifying to the intensive oil production and the value of the esate and the possible inheritence of it.

Keywords: Podstrana; Decimius Maksim Ausonius; Julius Ausonius; Lucius Artorius Casust and the agrarian conflict. 